\title{
Erratum
}

\section{The Guardianship Dilemma: Regime Security through and from the Armed Forces-ERRATUM}

\author{
R. BLAKE MCMAHON and BRANISLAV L. SLANTCHEV University of \\ California-San Diego
}

doi:10.1017/S0003055415000131, Published by Cambridge University Press 23, April 2015

$\mathbf{O}$

wing to an editorial oversight, the citation and reference for Piplani and Talmadge (2015) was deleted twice on page 307 of the May 2015 issue of American Political Science Review. The citations should read as follows:

In this context, it is useful to consider the empirical results of two studies that find that the probability of coups is lower if the country is involved in a war (Piplani and Talmadge, 2015) and even in a crisis (Arbatli and Arbatli, 2014). The explanatory mechanisms these studies offer are different (although not necessarily incompatible): Piplani and Talmadge (2015) argue that when the military is engaged in a war there are fewer opportunities for a coup and more uncertainty about who will join it, whereas Arbatli and Arbatli (2014) argue that crises allow rulers to commit credibly to transfers to the military and to generate rally-around-the-flag effects.

Also, owing to a printer's error on page 305, Qaddafi is misspelled as Qaddaf.

We regret these errors.

\section{REFERENCES}

Arbatli, Cemal Eren, and Ekim Arbatli. 2014. "External Threats and Political Survival: Can Dispute Involvement Deter Coup Attempts?" Conflict Management and Peace Science.

McMahon, R. Blake, and Branislav L. Slantchev. 2015. "The Guardianship Dilemma: Regime Security through and from the
Armed Forces." American Political Science Review 109 (2): 297 313. doi:10.1017/S0003055415000131.

Piplani, Varun, and Caitlin Talmadge. 2015. "When War Helps Civil-military Relations: Prolonged Interstate Conflict and the Reduced Risk of Coups." Journal of Conflict Resolution. DOI: $10.1177 / 0022002714567950$. 